Article

\title{
Replacing Work with Study: A Sustainable Development Strategy for Economically or Culturally Disadvantaged Students
}

\author{
Yi-Chih Lee
}

check for updates

Citation: Lee, Y.-C. Replacing Work with Study: A Sustainable Development Strategy for Economically or Culturally Disadvantaged Students. Sustainability 2021, 13, 9658 https://doi.org/10.3390/ su13179658

Academic Editors: Ana B. Bernardo, Adrian Castro-Lopez, Javier Puente and Leandro Almeida

Received: 14 August 2021

Accepted: 24 August 2021

Published: 27 August 2021

Publisher's Note: MDPI stays neutral with regard to jurisdictional claims in published maps and institutional affiliations.

Copyright: (C) 2021 by the author. Licensee MDPI, Basel, Switzerland. This article is an open access article distributed under the terms and conditions of the Creative Commons Attribution (CC BY) license (https:// creativecommons.org/licenses/by/ $4.0 /)$.
Department of International Business, Chien Hsin University of Science and Technology, Taoyuan City 320312, Taiwan; leeyc@uch.edu.tw

\begin{abstract}
Education is one of the most effective ways to eradicate and reduce poverty, helping to eliminate it as well as to promote social mobility. Although universities have been extensively established in Taiwan, the country still faces the problem of a large difference in students' academic ability and a widening gap in educational resources among families. This study mainly explored whether the strategy of encouraging learning instead of working for disadvantaged students is helpful to their learning effectiveness. The research samples were collected from the data of college students who participated in the higher education SPROUT project of Taiwan's Ministry of Education. This study enrolled a total of 752 students categorized as disadvantaged. The results found that those students who participated in the project usually devoted more time to study and schoolwork, and so they passed more subjects in the schoolwork with better overall performance in learning. They also obtained the required licenses for employment and more student subsidies to improve their lives. Therefore, the conclusion of this study is that by participating in multiple counseling mechanisms such as schoolwork counseling, license counseling, or career counseling arranged by universities, disadvantaged students can increase their study time, which not only improves their schoolwork learning effects but also enhances their employability.
\end{abstract}

Keywords: disadvantaged students; higher education SPROUT project; learning effects

\section{Introduction}

The United Nations (2020) has pointed out that nearly 260 million children worldwide were unable to go to school normally in 2018, with poverty and discrimination as the main causes of education inequality. UNESCO reported that in many countries, children from poor communities, girls, people with disabilities, immigrants, and ethnic minorities are in a severely disadvantaged position in regard to education. In 2018, 258 million children and adolescents worldwide were completely unable to receive education, accounting for about $17 \%$ of global school-age children, with poverty as the main reason for their failure to go to school, and most of them live in South Asia, Central Asia, and Southern Africa [1].

The reasons for the term "disadvantaged" may be nationality, ethnic group, economy, culture, language, region, or other factors. However, the factors leading to students being at a disadvantage are diverse and complex, and so one of the main topics often discussed is being economically disadvantaged-that is, the problem of "poverty" [2]. Due to a lack of resources (money being the main source), many people live a life that is lower than the minimum moderate economic resource standard or even below their needs and expectations, which is called poverty [3]. Scholars have argued that poverty affects learning attitudes, learning motivations, and academic achievements [4]. In Australia, economically disadvantaged students also have a poor reading intelligence level [5]. Students from high-income families have more exposure to better resources than students from lowincome families. In addition, parents with high socioeconomic status can provide cultural 
capital and social capital to their children, while children from poor families lack such resources $[4,6-9]$.

UNESCO (2017) pointed out that education itself is not only a goal pursued by individuals but also a means of other sustainable development goals. Education is an internal component of sustainable development and is also a key factor to promote the realization of sustainable development [10]. On 25 September 2015, the United Nations General Assembly adopted the 2030 Agenda for Sustainable Development [11], which put forward 17 Sustainable Development Goals, including those related to education. These include "No Poverty", as education is one of the most effective approaches to reducing poverty, and "Quality Education", ensuring inclusive and fair quality education so that all people can enjoy opportunities for lifelong learning to master necessary knowledge and skills and to fully integrate into society. These all represent the importance of education among the Sustainable Development Goals [11]. With the rapid changes in the world, the knowledge update cycle has become shorter, and so the provision of high-quality education and the development of lifelong learning attitudes have become important basic competencies for all students. Many studies have also noted that schools are regarded as an effective intervention in solving the disadvantages of low socio-economic backgrounds [12-14]. People can also reverse poverty through education, which further promotes social strata flow.

According to Effectively Maintained Inequality (EMI) [15] proposed by Lucas (2001), even though the enrollment rate of higher education tends to be high in the United States, the social and economic background of the family still has a great impact on the fairness of higher education opportunities, and both quantitative and qualitative unfairness are factors in the distribution process of higher education. Quantitative unfairness means that the proportion of the population receiving the same level of education in the advantaged groups is higher than that in the disadvantaged groups; qualitative unfairness means that the quality of education received by the advantaged groups is higher than that by the disadvantaged groups. As a result of the expansion, there has been stratification in higher education, and there is a difference in the values of diplomas obtained from different types of educational institutions in the labor market. After the number of people in the advantaged groups receiving higher education reaches saturation, the remaining opportunities can be enjoyed by the disadvantaged groups in reality. However, the educational opportunities that the disadvantaged groups can enjoy are from educational institutions with low diploma value, which causes another unfair phenomenon [16].

In Taiwan, higher education is divided into several types, including "academic" universities that train academic research talents and "technical and vocational" universities that mainly teach applied science and technology courses to train practical professionals [17]. In addition, the ranking of departments in public universities is generally better than that in private universities. Since public universities receive a large number of education subsidies from the government, their tuition fees are relatively low. However, the proportion of students from disadvantaged families in public universities is less than that in private universities. In the labor market, compared with private university graduates, public university graduates are often regarded as a group of people with better human qualities and are generally accepted by business owners [18]. Students with higher average monthly family income have higher admission rates in Taiwan. Therefore, they can enroll at public universities and pay the least tuition fees but enjoy more government education subsidies and better education quality $[19,20]$. On the contrary, students with poor family backgrounds usually have poor test scores and can only enroll at private universities or technical and vocational universities [21] and pay high tuition fees while receiving fewer government education subsidies and in some cases having to work part-time to pay tuition fees. Furthermore, after their graduation, in addition to having to repay the loans of universities, their employment conditions are not as good as those of ordinary students.

Several authors have presented different projects developed with the aim of helping disadvantaged students, such as: selecting the disadvantaged students in the most vulnerable areas to give financial subsidies for schooling [22], enhancing the provision of library 
resources for disadvantaged students [23], providing scholarships [24], providing additional courses [25], and assessing the background factors of schoolchildren and providing scholarships to schoolchildren to increase re-enrollment opportunities [26]. Giving extra grants and providing educational resources have become the main methods for countries to help disadvantaged students. However, when a policymaker allocates resources to schools, they cannot give advice on the best allocation, and the resources given are often limited. In order to maximize resource efficiency, the subsidized units usually adopt different methods of helping students according to the characteristics of the target students. The disadvantaged students often need to spend a lot of time working to earn money for personal expenditure, so they have to sacrifice their study time, which results in low academic performance or even suspension or withdrawal from university. As a result, the poor students with economical disadvantages jointly suffer from educational disadvantages and fall into a vicious circle. In order to break this phenomenon of unequal education, the main motivation of this student aid measure is to encourage students to transfer their limited time from working to earn money to reading to earn money. On the one hand, students are encouraged to read more books to ensure better academic performance. On the other hand, they are also encouraged to spend time learning employment skills. All the time spent participating in learning can be exchanged for grants as living expenses, so that they can earn living expenses while studying, taking into account both study and life. Therefore, this program is aimed at disadvantaged university students. The main contribution of this study is that the studying and the employment skills training were integrated. In addition to providing scholarships for outstanding students, rich curriculum education and additional curriculum training were also provided to train students' employment skills and improve their academic learning effectiveness. Learning autonomy is exercised by students so that the disadvantaged students can choose the most favorable teaching program for their actual needs. Thus, the barriers of educational inequality are expected to be eliminated for socially and economically disadvantaged ethnic groups.

In summary, this study analyzed the following issues.

1. The correlation between the utilization rate of financial aid resources and academic performance of students who are economically or culturally disadvantaged.

2. The gender differences in the use of student aid resources by students who are economically or culturally disadvantaged.

3. The difference in the utilization rate of student aid resources among different groups of economically or culturally disadvantaged students.

\section{Literature Review}

\subsection{Disadvantages}

As pointed out by the United Nations (2021), poverty denotes not only the lack of income and resources that make it difficult to maintain daily life but also hunger, malnutrition, the inability to obtain a full education, social discrimination or exclusion, the failure to enjoy basic public services, reduced access to loans from the capital market [27]. In 2015, more than 736 million people were living below the international poverty line, and more than $10 \%$ of the world's population cannot even have their basic needs met for medical care, education, water, and sanitation. Therefore, eradicating all forms of poverty is one of the 17 goals of the 2030 Agenda for Sustainable Development [28]. Taiwan's official definition of low-income households is based on the poverty line as the poverty threshold - that is, the minimum cost of living is employed as the demarcation point of the poverty line, and those people below the level of personal income are the poor [2].

According to United Nations statistics (2020) [29], the global indigenous population only accounts for $5 \%$ of the world's total population, but it accounts for as much as $15 \%$ of the world's poor population. The main cause is the inequality of education. In addition, the disadvantaged ethnic groups around the world, compared with the local advantaged ethnic groups, usually have lower academic performance, shorter education years, and poorer overall education quality, with an example being the aborigines in 
Taiwan [30]. Formal education often ignores various traditions of indigenous peoples, with languages, teachers, teaching contents, and methods dominated by mainstream ethnic groups, resulting in systemic inequality in educational opportunities and education quality for indigenous peoples, making them face urban-rural gaps, maladjustment, and living restrictions or other factors, compromising their learning experience and even forcing them to suspend their studies [31]. In Taiwan, during the 2018 academic year the suspension rate of indigenous students in colleges and universities was as high as $8.6 \%$ (the same rate was $6.2 \%$ for general students), and the dropout rate reached $12.8 \%$ ( $7.1 \%$ for general students) [32]. Thus, indigenous students have also become another disadvantaged group in society. Tabi (2016) considered that the challenge faced by many ethnic minority students is the lack of skills that can help them successfully adapt to the university environment. Therefore, Tabi (2016) suggested that supportive strategies such as guidance, counseling, and providing care are beneficial to ethnic minority students [33].

The disadvantages of such students are obviously seen in their studies. The main reasons are that they have received grandparenting, are new residents, or are from economically or culturally disadvantaged families such as having single parents [34], and so their parents are busy with livelihoods and have less or no time to care about their children's education. Therefore, the performance in learning for disadvantaged students is poorer than average in terms of learning motivation and learning self-efficacy [35]. Hung (2001) noted that remedial education programs for disadvantaged students usually fail to achieve the expected results, and so substantial help can only be realized by providing appropriate assistance based on the actual difficulties faced by the students [36].

\subsection{Equality of Educational Opportunity}

In the case of limited social resources, how to allocate them, and to whom, a set of principles of fairness and justice is required as the allocation standard. In terms of the argument of the equality of educational opportunity, Coleman [37] pointed out that in different social and economic countries, in pursuit of equality of educational opportunities, the schools play a role in providing specific educational resources and protecting schoolchildren from being exploited by family impact, so that schoolchildren can freely enjoy these resources for their benefits. Volmink (1994) emphasized that the function of schools is to enable students to achieve a performance level of making the best preparations for their future lives. Schools have the responsibility to create fair competition opportunities for each student and not to allow some students to be discriminated against due to their relatively poor academic performance or even deprived of the opportunity to compete fairly with others [38].

The basic argument of educational equality theory is that school education is a preparation field for individuals to participate in the market economy and pursue other social achievements. Meanwhile, the educational achievements of a person have high correlation with other social achievements. Since the fairness of access to educational resources seriously affects the competitiveness of an individual in the labor market, educational equality theorists emphasized the fairness of competition, and they argued that the opportunity for individuals to obtain educational achievements should not be affected by factors beyond their control. In addition, the educational resource allocation in line with the principle of equality should depend on individual talents and efforts, rather than on social class or family background; that is, individual educational opportunities should be guaranteed to be not affected by class or family [39-41].

Undoubtedly, education is a kind of public goods. However, education is also a kind of private goods at the same time, and it is a kind of private goods linked to status, a form of positional goods that can be used to improve work income and enhance social status and prestige for students [42]. As a type of positional goods, education has two forms of benefits. One is the admission benefit of education: A well-educated person finds it easier to enroll at a good follow-up school. The other is the earnings benefit of education: A well-educated person has access to jobs with high salary and high social status $[43,44]$. The investment in 
education can be transformed into an advantage in the labor market and competition for social or political positions. If parents with better resource conditions send their children to private schools or transfer them to star school districts in pursuit of better education quality, when their children gain these advantages, they may make the children who were originally at a disadvantage even more disadvantaged [45]. Therefore, educational equality theorists advocated for the state to enact policies to address the issue of children's learning weakness caused by parents' economic weakness or neglect of children's education or to provide more educational resources as compensatory measures to correct this situation [41].

\subsection{Higher Education Sustained Progress and Rise of Universities in Taiwan (SPROUT) Project}

In order to help economically or culturally disadvantaged students to receive a smooth university education, the Taiwan government provides a student aid program for students in colleges and universities whose family income is in the bottom $40 \%$. The project measures include the four items of student subsidies, living subsidies, emergency relief grants, and accommodation discounts, which provide subsidies for students' tuition and fees, living expenses, emergency relief funds, and accommodation expenses. Among them, the living assistance measures for disadvantaged students include exemption or reduction of tuition and miscellaneous fees, assistance with school loans, emergency relief and foreign student loans, as well as grants and scholarships for studying abroad [46].

1. Student subsidies: The subsidies ranging from TWD 5000 to 35,000 (USD 178-1250) are provided to students whose family's annual income is below TWD 700,000 (approximately USD 25,000 ) to reduce their burden of tuition and fees, based on the nature of the public or private school and the family's annual income.

2. Living subsidies: Disadvantaged students are provided with monthly living expenses of TWD 3000 (approximately USD 100) or more.

3. Emergency relief grants: Schools can provide funds as temporary relief grants to those students in financial difficulties due to an emergency in their families.

4. Accommodation discounts: Free accommodation for on-campus dormitories is provided for low-income students, and priority is offered to low- and middle-income students for accommodation in on-campus dormitories.

5. Exemption or reduction of tuition and miscellaneous fees: Low-income students are exempt from tuition and miscellaneous fees; middle- and low-income students enjoy a $60 \%$ reduction of tuition and miscellaneous fees. Disabled students and children of persons with disabilities: Tuition and miscellaneous fees are free for those with severe or very severe disabilities; those with moderate disabilities enjoy a $70 \%$ reduction in tuition and miscellaneous fees; those with mild disabilities are entitled to a $40 \%$ reduction in tuition and miscellaneous fees; and children or grandchildren of families of special circumstances can receive a $60 \%$ reduction of credit tuition and miscellaneous fees as per the actually charged credit tuition and miscellaneous fees or fees for the universities and colleges. Aborigines are offered a fixed amount of reduction from TWD 11,000 to 44,000 based on the department of education or subject.

6. School loans: Loans for tuition and miscellaneous fees, internship fees, book fees, accommodation fees, student group insurance fees, overseas training fees, living expenses for low-income and middle-income households, and computer and network communication fees are available for families whose annual income is TWD 1.2 million or less.

7. Emergency relief: The government provides assistance for unexpected economic changes to students who have an emergency or a family with an emergency.

8. International student loans and grants for studying abroad: Low-interest loans for studying abroad are also provided in addition to publicly funded examinations for overseas study.

To accelerate the function of higher education to promote class mobility, the Ministry of Education has also introduced an in-depth study assistance mechanism. It encourages colleges and universities to provide study guidance for disadvantaged students and of- 
fer internship opportunities, career planning assistance, society feedback, and student fundraising, so that the economically and culturally disadvantaged students can take care of both schoolwork and daily needs at the same time through the tutoring mechanism of study grants [47].

\section{Materials and Methods}

\subsection{Classification of Disadvantaged Students}

According to the standards set by the program, the criteria for students to be considered economically disadvantaged or culturally disadvantaged are: (1) indigenous people; (2) low-income households: (a) after the total family income is equally distributed to all family members, the income of each member per month is below the minimum living allowance for the local area; (b) the family property does not exceed the value applicable to low-income households for the local area; (3) low- and middle-income households: (a) after the total family income is equally distributed to all the family members, the income of each member per month is below 1.5 times the minimum living allowance for the local area; (b) the family property does not exceed a certain amount for the local area applicable to lowand middle-income households; (4) children of persons with disabilities; (5) students with disabilities; and (6) children or grandchildren of families in special circumstances: Families in special circumstances refer to those families in which the income of each member does not exceed 2.5 times the minimum living expenses determined the government for the year or 1.5 times the average monthly consumption expenditure per person in Taiwan after the total family income is equally distributed to all family members, the family property does not exceed a certain amount determined by the central competent authority, and one of the following circumstances applies: (a) under 65 years of age, his or her spouse died or disappeared and has not been found for more than six months after the disappearance was reported to the police for search assistance; (b) unable to live together with the spouse due to malicious abandonment or abuse by the spouse, the divorce is confirmed by judgment, or the registration of divorce agreement has been completed; (c) victim of domestic violence; (d) an unmarried pregnant woman of more than three months of pregnancy up to within two months of childbirth; or (e) independently raising a child under the age of 18 due to divorce, widowhood, giving birth out of wedlock, or a grandchild under the age of 18 whose parents are unable to support them and is incapable of working or unable to work due to serious injuries or taking care of a child under the age of six although he or she is capable of working $[48,49]$.

\subsection{Research Design}

This student aid program is divided into five counseling mechanisms, namely, academic scholarships, attending license counseling courses, obtaining professional license subsidies, participating in lectures, and participating in off-campus competitions. Students who complete any of these five counseling mechanisms can receive different amounts of scholarships. Students may participate in all or choose their interested items, without a limit in the number of participants. After participation, they can apply for grants from the organizers based on the participation results. The greater number of participants, the more scholarships are obtained.

1. Academic scholarships: Students who choose and participate in their interested afterschool academic counseling courses with the required academic scores and the degree of absenteeism less than the prescribed number of classes are awarded scholarships.

2. Attending license counseling courses: Students who attend license counseling courses with a classroom attendance rate higher than $80 \%$ are given grants after the end of courses.

3. Obtaining professional license subsidies: All industries related to public safety or that are capable of affecting the personal life and property safety of consumers need licenses to practice, such as lawyers, accountants, medical personnel, fire safety equipment and device maintenance, and industrial power distribution [50]. In order 
to enhance the employment opportunities of students after graduation, students who obtain government department licenses or school-designated licenses during their studies are given different amounts of rewards according to different license levels, in addition to license registration fee subsidies.

4. Participating in lectures: In order to help students understand workplace trends before graduation and find their own interests and directions for employment as soon as possible, the schools can hold several workplace lectures, and students can accumulate points when participating in lectures. Students who accumulate more than two points are given grants.

5. Participating in off-campus competitions: Economically or culturally disadvantaged students are encouraged to participate in competitions held inside and outside universities, so as to enhance the self-learning atmosphere and show learning achievements. Students who participate in competitions of different scales and win prizes are given different bursaries.

\subsection{Research Samples and Period}

The data of this study were taken from the data of university students who are disadvantaged. The data collection period was from 1 August 2019 to 31 July 2020. The students included all grades of students from freshman to senior, and their study periods were during the daytime, the nighttime, and holidays. Students who had only attended one semester were excluded from the data samples, whereas the rest were included in the database for analysis. In the samples, students who had participated in one counseling mechanism were classified into the experimental group, while those who had not participated in any counseling mechanism were classified into the control group.

\subsection{Analysis}

This study used the Statistical Package for the Social Sciences (version 21.0 IBM SPSS Inc, Chicago, IL, U.S.A.) to perform various statistical analyses. Statistical methods such as mean, standard deviation, range, ANOVA, and regression were adopted to perform the overall sample variable analysis for descriptive statistics, and 0.05 was taken as the test level for statistical significance.

\section{Results}

This study included a total of 752 students who met the disadvantaged classification and had complete school-year data, including 459 (61.04\%) males and 293 (38.96\%) females, with an average age of 22.94 years old (STD 5.17). There were 78 students $(10.37 \%)$ from low- and middle-income households, 144 (19.15\%) students from low-income households, $230(30.59 \%)$ students that are children of persons with disabilities, $122(16.22 \%)$ students with disabilities, 149 indigenous students (19.81\%), and $29(3.86 \%)$ students from families with special circumstances. Among all samples, 405 students participated in the higher education SPROUT project, including 230 males (56.79\%) and 175 females (43.21\%), with an average age of 22.35 years old (STD 4.22). There were 49 students (12.09\%) from low-income households and 67 students (16.54\%) from low- and middle-income households, while 131 are the children of persons with disabilities (32.35\%), 73 are students with disabilities (18.02\%), $72(17.78 \%)$ are indigenous students, and $13(3.22 \%)$ are students from families with special circumstances, as shown in Table 1. 
Table 1. The description of the sample.

\begin{tabular}{cccc}
\hline Groups & The Overall Sample & Participants & Non-Participants \\
\hline $\begin{array}{c}\text { Low- and middle-income } \\
\text { households }\end{array}$ & 78 persons $(10.37 \%)$ & 49 persons $(12.09 \%)$ & $29(8.36 \%)$ \\
Low-income households & 144 persons $(19.15 \%)$ & 67 persons $(16.54 \%)$ & $77(22.19 \%)$ \\
$\begin{array}{c}\text { Children of persons with } \\
\text { disabilities }\end{array}$ & 230 persons $(30.59 \%)$ & 131 persons $(32.35 \%)$ & $99(28.53 \%)$ \\
$\begin{array}{c}\text { Students with disabilities } \\
\text { Indigenous people }\end{array}$ & 122 persons $(16.22 \%)$ & 73 persons $(18.02 \%)$ & $49(14.12 \%)$ \\
$\begin{array}{c}\text { Families with special } \\
\text { circumstances }\end{array}$ & 29 persons $(3.86 \%)$ & 13 persons $(3.22 \%)$ & $77(22.19 \%)$ \\
Total & 752 & 405 & $16(4.61 \%)$ \\
\hline
\end{tabular}

In the overall sample, students of different types of identity showed statistically significant differences in academic performance $(p=0.003)$, with low- and middle-income students having the highest score of $78.84( \pm 8.64)$, children of persons with disabilities having the second highest score of $75.48( \pm 11.30)$, and indigenous students obtaining the lowest score of $72.62( \pm 12.16)$. In addition, the number of failed academic subjects of the overall sample was also statistically significantly different $(p=0.023)$. The students from low-income households obtained the highest number of failed academic subjects, with an average of 1.81 subjects (range $0-15$ ), followed by 1.80 subjects (range $0-16$ ) for indigenous students, and 0.85 subjects (range $0-9$ ) for students from low- and middleincome households, which was the lowest number of failed subjects. Furthermore, there was also a statistically significant difference in the overall sample for the number of absences in the school year $(p<0.001)$. Indigenous students asked for leave most frequently, with an average of 76.98 lessons (range of $0-335$ ), followed by 56.27 for the students from low-income households (range of 0-403), and the leave requested by the students from low- and middle-income households was the lowest at 41.26 lessons (range of 0-213). In terms of gender, females had better academic performance than males (77.48 vs. 72.77 , $p<0.001)$, they failed in fewer subjects $(1.13$ vs. $1.61, p=0.010)$, and their number of requests for leave was higher, but there was no statistically significant difference (59.81 vs. 53.05, $p=0.164)$. When the groups were distinguished by participation in the program, those who participated in the program performed better than those who did not, with a higher average score $(78.55$ vs. $69.81, p<0.001)$. At the same time, they failed in fewer subjects ( 0.67 vs. 2.35, $p<0.001)$ and made fewer requests for leave (45.27 vs. $67.79, p<0.001)$. In addition, the number of licenses required for employment obtained by students participating in the program was much higher than that of students who did not participate in the program, and none of the students who did not participate in the program won prizes in the competitions inside and outside the school, as shown in Table 2.

Table 2. Learning performance between two groups.

\begin{tabular}{cccc}
\hline Variables & Participants & Non-Participants & $p$ Value \\
\hline Average score & $78.55($ SD 8.16$)$ & $69.81($ SD 13.26) & $<0.001^{*}$ \\
Failed academic subjects & 0.67 (Range 0-12) & 2.35 (Range 0-16) & $<0.001^{*}$ \\
Number of absences & 45.27 (Range 0-335) & 67.79 (Range 0-403) & $<0.001^{*}$ \\
License number & 0.39 (Range 0-5) & 0.01 (Range 0-1) & $<0.001^{*}$ \\
\hline
\end{tabular}
Mean (SD or range); ${ }^{*} p<0.05$.

From the perspective of identity, there were statistical differences in the academic performance of the whole school year $(p=0.039)$. The students from families with special circumstances had the best academic performance after participating in the higher education SPROUT project, with a score of 80.33 points (STD 9.14), while the indigenous students had the worst performance of 76.25 points (STD 8.89). In terms of class attendance, there were differences between different identities $(p=0.009)$; the indigenous students had the worst attendance, with an average number of absences of 66.65 lessons (range of 
0-335), and the students in families of special circumstances had the best attendance, with an average number of absences of 30.09 lessons (range of 6-74). However, there was no statistical difference in the use of aid funds and the number of failed subjects.

Further analysis showed no significant difference in academic performance, number of failed subjects, or number of days off for female students of each identity category, but for male students, there was a statistically significant difference in the academic performance of each identity category $(p=0.003)$ and the number of requests for leave $(p=0.007)$. Among them, students from families with special circumstances performed better and obtained 81.38 points $( \pm 7.05)$, and the indigenous students had the worst performance of 72.20 points $( \pm 8.90)$. The indigenous students requested the highest number of days off and obtained 75.94 points (range of 0-335), and the students from low-income households asked for the smallest number of absences, which was 29.39 lessons (range of 0-126). Gender did not cause any difference in the use of grants for students of different identities.

In the counseling program, students mostly chose to participate in academic scholarships (50.0\%), followed by attending license counseling courses (17.8\%). The top two counseling programs that male students participated in were academic scholarships and license counseling courses, while female students chose to participate in academic scholarships and professional license subsidies. In terms of analysis of the participation of counseling programs, the participation of children with physical and mental disabilities was the highest, as shown in Table 3.

Table 3. Number of students with different identities participating in counseling programs (multi-choice option).

\begin{tabular}{|c|c|c|c|c|c|}
\hline $\mathrm{X}^{2}$ Programs & $\begin{array}{c}\text { Academic } \\
\text { Scholarships }\end{array}$ & $\begin{array}{l}\text { Attending } \\
\text { License } \\
\text { Counseling } \\
\text { Courses }\end{array}$ & $\begin{array}{l}\text { Obtaining } \\
\text { Professional } \\
\text { License } \\
\text { Subsidies }\end{array}$ & $\begin{array}{l}\text { Participating } \\
\text { in Lectures }\end{array}$ & $\begin{array}{c}\text { Participating } \\
\text { in Off-Campus } \\
\text { Competitions }\end{array}$ \\
\hline $\begin{array}{c}\text { Low and middle-income } \\
\text { households }\end{array}$ & 32 & 15 & 14 & 8 & 8 \\
\hline Low-income households & 55 & 18 & 14 & 10 & 9 \\
\hline $\begin{array}{l}\text { Children of persons with } \\
\text { disabilities }\end{array}$ & 101 & 25 & 36 & 11 & 13 \\
\hline Students with disabilities & 58 & 23 & 20 & 9 & 3 \\
\hline Indigenous people & 46 & 22 & 15 & 9 & 5 \\
\hline $\begin{array}{l}\text { Families with special } \\
\text { circumstances }\end{array}$ & 11 & 5 & 3 & 3 & 2 \\
\hline
\end{tabular}

Based on the analysis of the performances of students participating in the program, the higher the amount of the grant received, the better the academic performance $(\beta=0.184$, $p<0.001)$. Among them, female students were more active in participating in the program than male students (TWD 6606 vs. TWD 5682, $p=0.016$ ) (Figure 1); therefore, the overall academic performance of female students was better than that of male students (80.24 vs. 77.26, $p<0.001$ ), and the number of failed subjects for female students was also smaller $(0.50$ vs. $0.80, p=0.025)$. Since students could freely choose to participate in several counseling programs, through the analysis of the number of counseling programs, students who participated in more programs obtained higher total scores in the semester, with a statistically significant difference $(p<0.001)$. In the post-inspection, the students who participated in three or four counseling programs had much better academic achievements than those who chose only one program ( $p=0.001$ vs. $p=0.005)$. However, there was no significant difference in the number of failed subjects and the number of absences, as shown in Table 4. 


\section{The utilization of grants}

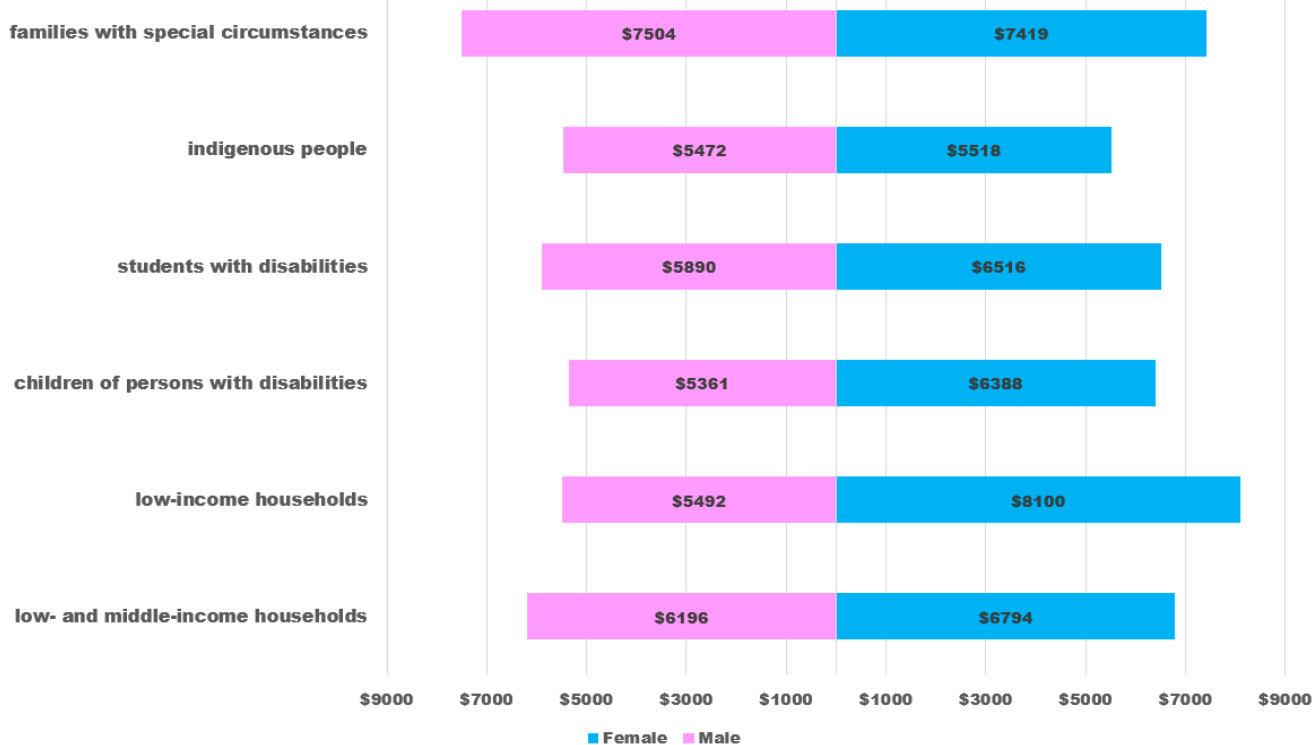

Figure 1. The utilization of grants.

Table 4. Learning performance among the number of participating programs.

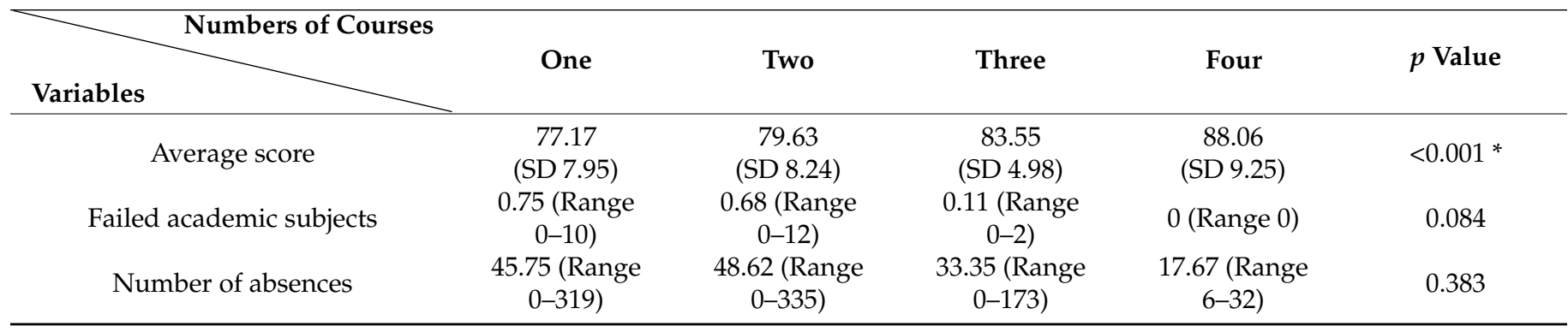

Mean (SD or range); ${ }^{*} p<0.05$.

\section{Discussion}

With the change of social patterns, the risks brought by social problems expand, leading to insufficient income and poverty and making the disadvantaged weaker and the poor poorer. People must make a choice when environmental resources are limited. Therefore, the government should integrate its resources with those of the education units, clearly define the disadvantaged who need to be taken care of, and choose to assist those who need the assistance most, rather than offer unlimited help to the disadvantaged students only because they are disadvantaged. The ultimate goal of education is to help the disadvantaged groups in need of assistance to gain a skill and rely on their own strength to achieve a sustainable life, as this is the purpose of maximizing the effectiveness of resources. Therefore, based on educational equity, Taiwan provides subsidies for the participation in different programs for schooling and employment activities to the six disadvantaged groups defined by the education units. It is hoped through participating in various activities that these students can obtain better learning results through sustainable learning. By learning employment skills via taking skill training courses or workshops, they are able to support their daily lives by obtaining subsidies and making a living by studying instead of working, thereby enhancing their future competitiveness. These efforts also echo the OECD's guidance that higher education institutions should provide additional support to students with disadvantaged backgrounds [51] in order to reach the target of equal educational opportunities advocated by the educational equality theory. Meanwhile, for 
these additional personnel training measures, different countries should take effective measures to create their own national characteristics.

As found in the research results, the students who participated in the higher education SPROUT project usually devoted more time toward studying. They also passed more subjects, and their overall performance was better. Students willing to participate more in the program activities can obtain higher subsidies, which can indeed improve their overall performance. Students in the experimental group obtained more practice licenses required for future employment than those who did not participate in the experimental group, which showed that the intervention of the program surely helped in the students' future employment competitiveness. The research also showed that female students were more active in participating in various activities of the program, and so their overall learning performance was better than that of male students, and the results also indicated gender differences in the use of subsidies and overall learning performance. Among the five counseling mechanisms, the students participated in the academic scholarships the most, and the students participating in more counseling programs not only obtained more grants but also showed better academic performance. Eventually, the target of the program that let students study more and attain more scholarships was achieved, that is, the target that let students not only reduce the pressure of their lives but also improve their academic and future employment capabilities.

It is worth discussing that the indigenous students, regardless of whether they participated in the improvement of the student aid program or not, had the worst academic performance, the worst attendance in class, and the least participation in the planned curriculum activities. Scholars [52] pointed out in studies that the poor academic performance of indigenous students is largely due to the impact of the poor socioeconomic background of their families. In addition, the ratio of families of indigenous students being low-income households, grandparenting, or single-parent upbringing is also higher than that of ordinary students. Besides the comparatively weaker family financial situations and parenting abilities, indigenous students generally have low interest in learning. Facing the more difficult educational content of universities, they are often relatively uninterested and have low levels of participation, which in turn affects their learning effectiveness. This study also showed similar results to those in the literature.

\section{Limitations}

This study did not provide individualized education courses for students of various disadvantaged identities. Instead, it only provided courses to strengthen the general academic and employability of various disadvantaged students. Therefore, the results showed the varied absorption of the integrated intensified education courses by students of different identities. In particular, it was found that the learning effectiveness of indigenous students in the higher education system was lower than that of ordinary students, and even their willingness to participate in the program was lower. It is suggested that follow-up researchers can provide an individualized education curriculum targeting the features of indigenous students. For example, they should cooperate with specific vocational training units to strengthen the training of employment skills for indigenous students, provide after-school tutoring and career planning guidance for indigenous students, or include the return of indigenous students to their hometown community services as part of the student award. Only by giving individualized considerations to the differences of individual students can the government affectively assist the performance of indigenous students in school. In addition, since the use of program funds was limited to students of Taiwanese nationality, a comparison between students with multiple nationalities cannot be made. Recently, due to the COVID-19 pandemic, students' schooling has been affected in many countries. In Taiwan, schools did not adopt online teaching courses until mid-May 2021 due to the pandemic. The disadvantaged students enjoyed fewer resources than ordinary students, and whether there is a loss of schooling rights caused by COVID-19 and resource restriction is worth discussing. 


\section{Conclusions}

Poor families have difficulties in life, and their children often do not receive a good education, which leads to their failure in obtaining an appropriate job when they grow up and makes it relatively difficult for them to earn a living. This vicious cycle from generation to generation has caused unfavorable living conditions for future generations and has continued to result in poverty and inequality [53]. As educational units, universities should provide students in need with substantial assistance methods to cultivate students' capability of sustainable learning. If disadvantaged students are forced to leave the educational field due to personal family or economic factors during their higher education, the equality of educational opportunity and the promotion of social mobility will become slogans. It is one of the Sustainable Development Goals of the United Nations to assist the disadvantaged groups to enhance their human capital and provide them with employability through education and training and to ensure that they have fair rights in the acquisition of resources [54]. According to the "asset-based welfare theory", to address the welfare needs of low-income households and special ethnic groups, the government needs to help them in developing human capital, building social capital, and participating in productive employment activities so that these ethnic groups can eventually become a part of the overall social productive economic activities $[55,56]$. Higher education in Taiwan is an important method for children from middle and low social classes to move upward. By participating in the diversified counseling mechanisms arranged by universities, such as homework counseling, license counseling, and career counseling, the disadvantaged students can reduce their working hours and increase their study time, which can not only achieve better schoolwork performance but also enhance their future employability. Thus, the ultimate target of the equality of educational opportunity in this student aid program will be truly achieved.

Funding: This research received no external funding.

Institutional Review Board Statement: Not applicable.

Informed Consent Statement: Not applicable.

Data Availability Statement: The data are not publicly available due to privacy issues and to ensure confidentiality of the participants.

Acknowledgments: I would like to acknowledge reviewers and editors.

Conflicts of Interest: The author declares no conflict of interest.

\section{References}

1. Yang, M.J.; Poverty and Discrimination. Radio Taiwan International. Available online: https://www.rti.org.tw/news/view/id/ 2069171 (accessed on 26 May 2021).

2. Liao, C.W.; Cheng, P.W. Longitudinal Study of Economically Disadvantaged Student's Learning Attitude and Academic Performance. J. Educ. Pract. Res. 2019, 32, 71-105.

3. Zhang, G.W. An analysis of poverty trends in Taiwan over the past decade-Taking 1994, 2001, and 2004 surveys of low-income households as examples. Community Dev. J. 2009, 124, 28-42. Available online: https://www.sfaa.gov.tw/SFAA/Pages/ashx/Fi le.ashx?FilePath= \{\}/File/Attach/1562/File_176480.pdf (accessed on 26 May 2021).

4. Shen, S.S. The Study on Poverty and Education: Educational Policy Review. J. Educ. Res. Dev. 2006, 2, 35-62.

5. $\mathrm{Ng}, \mathrm{C}$. Using student voice to promote reading engagement for economically disadvantaged students. J. Res. Read. 2018, 41, 700-715. [CrossRef]

6. Donnelly, M. The road to Oxbridge: Schools and elite university choices. Br. J. Educ. Stud. 2014, 62, 57-72. [CrossRef]

7. Donnelly, M. Progressing to university: Hidden messages at two state schools. Br. J. Educ. Stud. 2015, 41, 85-101. [CrossRef]

8. McKnight, A. Downward Mobility, Opportunity Hoarding and the ‘Glass Floor'. Centre for Analysis of Social Exclusion (CASE) Report. Available online: https:/ / dera.ioe.ac.uk/23370/1/Downward_mobility_opportunity_hoarding_and_the_glass_floor.pdf (accessed on 29 July 2021).

9. Thiele, T.; Pope, D.; Singleton, A.; Snape, D.; Stanistreet, D. Experience of disadvantage: The influence of identity on engagement in working class students' educational trajectories to an elite university. Br. Educ. Res. J. 2017, 43, 49-67. [CrossRef]

10. UNESCO. Education for Sustainable Development Goals: Learning Objectives. Available online: https://unesdoc.unesco.org/ark: /48223/pf0000247444 (accessed on 10 May 2021). 
11. United Nations. Take Action for the Sustainable Development Goals. Available online: https://www.un.org/sustainabledevelo pment/sustainable-development-goals / (accessed on 12 May 2021).

12. Koedel, C. An empirical analysis of teacher spillover effects in secondary school. Econ. Educ. Rev. 2009, 28, 682-692. [CrossRef]

13. Rivkin, S.G.; Hanushek, E.A.; Kain, J.F. Teachers, schools, and academic achievement. Econometrica 2005, 73, 417-458.

14. Bellibas, M.S. Who are the Most Disadvantaged? Factors Associated with the Achievement of Students with Low Socio-Economic Backgrounds. Educ. Sci. Theory Pract. 2016, 16, 691-710.

15. Lucas, S.R. Effectively Maintained Inequality: Education Transitions, Track Mobility, and Social Background Effects. Am. J. Sociol. 2001, 106, 1642-1690. [CrossRef]

16. Council for Economic Planning and Development, Executive Yuan. The Analysis and the Development of Talent Cultivation Policies for Economically Disadvantaged Students. Available online: https://ws.ndc.gov.tw/Download.ashx?u=LzAwMS9hZG 1pbmlzdHJhdG9yLzEwL3JlbGZpbGUvNTY3Mi80Mjc1LzAwMTg1MjUucGRm\&n=5oiR5ZyL5o6o5YuV57aT5r\%2Bf5byx5Yui5 a2455Sf5LmL5Lq65omN5Z\%2B56IKy5pS\%2F562W5YiG5p6Q6IiH55m85bGVLnBkZg\%3D\%3D\&icon=.pdf (accessed on 29 July 2021).

17. Ministry of Education. The Standard Classification of Education of the Republic of China. Available online: https://stats.moe.go v.tw/files/bcode/105bcode_book.pdf (accessed on 20 July 2021).

18. Chang, J.J. The Equity Effects of Three Higher Education Policies in Taiwan. Taiwan Econ. Rev. 2013, 41, $443-484$.

19. Zhang, D.F.; Ye, L.Q.; Zhang, Y.H. The Multiple Entrance Programs for the Universities and Their Impacts on the Equality of Opportunities. Educ. Policy Forum 2005, 8, 1-23.

20. Cheng, Y.Y.; Fang, D.L.; Chuang, S.Y.; Chen, L.M.; Liu, M.J. Expanding Access to and Participation in Higher Education for Low-SES Students: Policy Analysis and Suggestions. J. Res. Educ. Sci. 2015, 60, 1-19.

21. Luoh, M.C. Educational Opportunities and Family Background in Taiwan. Taiwan Econ. Rev. 2004, 32, 417-445.

22. Henry, G.T.; Fortner, C.K.; Thompson, C.L. Targeted Funding for Educationally Disadvantaged Students: A Regression Discontinuity Estimate of the Impact on High School Student Achievement. Educ. Eval. Policy Anal. 2010, 32, 183-204. [CrossRef]

23. Reading, J. Providing Enhanced Information Skills Support to Students from Disadvantaged Backgrounds: Western Sydney University Library Outreach Program. J. Acad. Librariansh. 2016, 42, 694-704. [CrossRef]

24. Ortega, J.; Gonzalez, J.M.; Crenshaw, N.; Snowden, K.; De Tantillo, L. Supporting Graduate Nursing Education for Students from Disadvantaged Backgrounds. J. Nurs. Educ. 2020, 59, 287-290.

25. Metz, A.M. Medical School Outcomes, Primary Care Specialty Choice, and Practice in Medically Underserved Areas by Physician Alumni of MEDPREP, a Postbaccalaureate Premedical Program for Underrepresented and Disadvantaged Students. Teach. Learn. Med. 2017, 29, 351-359. [CrossRef] [PubMed]

26. Figueroa, J.L.; Van de gaer, D. Did Progresa Reduce Inequality of Opportunity for School Re-enrollment? Econ. Dev. Cult. Chang. 2021, 69, 541-567. [CrossRef]

27. Coco, G.; Pignataro, G. Unfair credit allocations. Small Bus. Econ. 2013, 41, 241-251. [CrossRef]

28. United Nations. Ending Poverty. Available online: https://www.un.org/en/global-issues/ending-poverty (accessed on 16 May 2021).

29. United Nations. UN International Day of the World's Indigenous Peoples. Available online: https://www.un.org/en/observan ces/indigenous-day (accessed on 16 May 2021).

30. Chang, C.C. Revisiting the Multicultural Myths. Bull. Educ. Res. 2014, 60, 111-128.

31. Teach for Taiwan. Educational Experience and Needs of Indigenous Peoples. Available online: https://www.teach4taiwan.org/b $\log / \% \mathrm{E} \% 8 \mathrm{E} \% 9 \mathrm{~F} \% \mathrm{E} 4 \% \mathrm{BD} \% 8 \mathrm{~F} \% \mathrm{E} 6 \% \mathrm{B0} \% 91 \% \mathrm{E} 6 \% 97 \% 8 \mathrm{~F} \% \mathrm{E} 7 \% 9 \mathrm{~A} \% 84 \% \mathrm{E} 6 \% 95 \% 99 \% \mathrm{E} \% 82 \% \mathrm{B2} \% \mathrm{E} 7 \% \mathrm{~B} 6 \% 93 \% \mathrm{E} 9 \% \mathrm{~A} 9 \% 97 /$ (accessed on 24 April 2021).

32. Department of Statistics of Ministry of Education. An Analysis of Aboriginal Education. 2018. Available online: http:/ / www.stat.org.tw/data/asoctopic/\%E5\%8E\%9F\%E4\%BD\%8F\%E6\%B0\%91\%E6\%97\%8F\%E6\%95\%99\%E8\%82\%B2\%E6 $\% \mathrm{~A} 6 \% 82 \% \mathrm{E} 6 \% \mathrm{~B} 3 \% 81 \% \mathrm{E} 5 \% 88 \% 86 \% \mathrm{E} 6 \% 9 \mathrm{E} \% 90$.pdf (accessed on 10 May 2021).

33. Tabi, M. Helping minority students from rural and disadvantaged backgrounds succeed in nursing: A nursing workforce diversity project. Online J. Rural. Nurs. Health Care 2016, 16, 59-75. [CrossRef]

34. Lin, H.C.; Chien, W.C. A Study on Learning Cultural Capital of Disadvantaged Students during the Summer Vacation in Urban Elementary Schools in Taiwan. J. Educ. Res. Dev. 2019, 15, 23-58.

35. Lee, Y.M. Discriminating Math Low-Achievement Motivation Patterns: Comparing Disadvantaged and Other Students in Elementary and Junior High School. J. Res. Educ. Sci. 2012, 57, 39-71.

36. Hung, L.Y. The study of remedial education for the disadvantaged students of compulsory education. J. Natl. Taiwan Norm. Univ. 2001, 46, 45-65.

37. Coleman, J.S. Equality and Achievement in Education; Westview: London, UK, 1990.

38. Volmink, J. Mathematics by All. In Cultural Perspectives on the Mathematics Classroom; Lerman, S., Ed.; Mathematics Educational Library; Springer: Dordrecht, The Netherlands, 1994; p. 14. Available online: https://link.springer.com/chapter/10.1007\%2F97894-017-1199-9_4 (accessed on 10 July 2021).

39. Brighouse, H. School Choice and Social Justice; Oxford University Press: London, UK, 2000.

40. Brighouse, H. Educational Equality and School Reform. In Educational Equality, 2nd ed.; Graham, H., Ed.; Continuum: New York, NY, USA, 2010; pp. 15-69. 
41. Chen, C.H. Equality or Adequacy? A Comparative Perspective on Justice in Education. J. Soc. Sci. Philos. 2016, $28,377-412$.

42. Hirsch, F. Social Limits to Growth; Harvard University Press: Cambridge, MA, USA, 1976.

43. Brighouse, H.; Swift, A. Equality, Priority, and Positional Goods. Ethics 2006, 116, 471-497. [CrossRef]

44. Koski, W.S.; Reich, R. When 'Adequate' Isn't: The Retreat from Equity in Educational Law and Policy and Why It Matters. Emory Law J. 2007, 56, 545-617.

45. Swift, A. How Not to Be a Hypocrite: School Choice for the Morally Perplexed Parent; Routledge: London, UK, 2003.

46. Ministry of Education. The Financial Aid Project for Economically Disadvantaged University Students. Available online: https: / / www.edu.tw/helpdreams/cp.aspx?n=294130B70B308624\&s=A8A03607552A5F17 (accessed on 4 April 2021).

47. Ministry of Education. Higher Education SPROUT Project. Available online: https://sprout.moe.edu.tw/SproutWeb/Project/Go alAndAch (accessed on 4 April 2021).

48. Department of Social Assistance and Social Work, Ministry of Health and Welfare. Qualifications. 2020. Available online: https:/ / dep.mohw.gov.tw / DOSAASW/cp-572-5035-103.html (accessed on 24 April 2021).

49. Department of Social and Family Affairs Administration, Ministry of Health and Welfare. Qualifications. 2014. Available online: https: / / www.sfaa.gov.tw/SFAA/Pages/Detail.aspx?nodeid=99\&pid=404 (accessed on 24 April 2021).

50. Liu, P.Y.; Guo, Y.C. The Study on Professional and Technical Workers' Qualifications and the Goal of Keeping the Tracks with Internationalization. Available online: https://ws.exam.gov.tw/Download.ashx?u=LzAwMS9VcGxvYWQvMS9yZWxmaWx ILzEyMDgyLzI4NDc4L2YzZjkxMmRiLTQzZGItNGE1Zi05NTYzLThmNTc0MmQ1MGJmMi5wZGY\%3D\&n=MjUxNTE0Mj A1NzEucGRm (accessed on 14 July 2021).

51. OECD. Tertiary Education for the Knowledge Society: Synthesis Report; OECD Publishing: Paris, France, 2008. Available online: https:/ / www.oecd.org/education/skills-beyond-school/41266690.pdf (accessed on 6 July 2021).

52. Lai, C.Y.; Wu, N.H.; Kuo, C.Y.; Wang, T.M. A Preliminary Investigation on Disadvantaged Education and Education Welfare Issues in Indigenous Villages in Taiwan: From the Perspective of Indigenous Principals. Soc. Policy Soc. Work 2013, 17, $213-258$.

53. Lin, W.Y.; Sun, J.Z.; Zheng, L.Z.; Wang, Y.C. Operation Manual of Independent Poverty Alleviation Program; Ministry of the Interior: Taipei, Taiwan, 2005.

54. Guterres, A. Remarks to Member States on Priorities for 2021. Available online: https://www.un.org/sg/en/content/sg/speech es/2021-01-28/remarks-member-states-priorities-for-2021 (accessed on 16 July 2021).

55. Midgley, J. Social Development: The Developmental Perspective in Social Welfare; Sage Publications: Thousand Oaks, CA, USA, 1995.

56. Chang, T.T.; Lu, L. The Effects of Resource Loss and Resource Gain on Work-Family Conflict: The Perspective of Resource Conservation. NTU Manag. Rev. 2009, 20, 69-98. 